\title{
Informational Urbanism. A Conceptual Framework of Smart Cities
}

\author{
Julia Barth \\ Heinrich Heine University \\ Düsseldorf \\ Julia.Barth@hhu.de \\ Aylin Ilhan \\ Heinrich Heine University \\ Düsseldorf \\ Aylin.Ilhan@hhu.de
}

\author{
Kaja J. Fietkiewicz \\ Heinrich Heine University \\ Düsseldorf \\ Kaja.Fietkiewicz@hhu.de \\ Agnes Mainka \\ Heinrich Heine University \\ Düsseldorf \\ Agnes.Mainka@hhu.de
}

\author{
Julia Gremm \\ Heinrich Heine University \\ Düsseldorf \\ Julia.Gremm@hhu.de \\ Christine Meschede \\ Heinrich Heine University \\ Düsseldorf \\ Christine.Meschede@hhu.de
}

\author{
Sarah Hartmann \\ Heinrich Heine University \\ Düsseldorf \\ S.Hartmann@hhu.de \\ Wolfgang G. Stock \\ Heinrich Heine University \\ Düsseldorf \\ Stock@phil.hhu.de
}

\begin{abstract}
Contemporary and future cities are often labeled as "smart cities," "digital cities" or "ubiquitous cities," "knowledge cities," and "creative cities." Informational urbanism includes all aspects of information and (tacit as well as explicit) knowledge with regard to urban regions. "Informational city" (or "smart city" in a broader sense) is an umbrella term uniting the divergent trends of informationrelated city research. Informational urbanism is an interdisciplinary endeavor incorporating on the one side computer science and information science as well as on the other side urban studies, city planning, architecture, city economics, and city sociology. In this article, we present both, a conceptual framework for research on smart cities as well as results from our empirical studies on smart cities all over the world. The framework consists of seven building blocks, namely information and knowledge related infrastructures, economy, politics (e-governance) and administration (e-government), spaces (spaces of flows and spaces of places), location factors, the people's information behavior, and problem areas.
\end{abstract}

\section{Introduction}

Nowadays, more than half of the world's population is living in cities. The world is still changing into an "urban world" [45]. This is the basic idea of our research program: Just as there were prototypical cities of the industrial society (for example, Manchester in middle of the $19^{\text {th }}$ century) or the service society (such as New York's Manhattan in the second half of the $20^{\text {th }}$ century), there are (or will be in the near future) typical cities of the knowledge society.

Sometimes, those cities are labeled as "smart." Additionally, there are further approaches conceptualizing cities and regions of the knowledge society: The terms "ubiquitous city” [74] and "digital city” [15] refer to the city’s well developed information and communication technology (ICT) infrastructures; research on the "knowledge city" concentrates on knowledge-based urban development and its institutions as higher education, science parks and libraries $[6,47]$, and, finally, "creative city" studies the "creative class" [23] as human capital in urban spaces. All mentioned approaches address in each case important topics of the description, analysis and planning of urban regions in contemporary and future cities of the knowledge era, but they do not reflect the whole story.

In contrast, in our interdisciplinary and holistic framework we study all aspects of knowledge and information, be it digital or physical, man or machine generated, which has implications for cities, their spaces, their institutions and-most important-their people. Albeit ICT is the heart of a smart city, we may not forget knowledge both in the form of tacit knowledge (bound to persons) as well as in the form of explicit knowledge (bound to documents [81]) [64]. Following Castells [7], we call such prototypical urban regions of the knowledge society "informational cities" [79] or "smart cities" (in the broader sense of the concept; see below!). Informational cities are studied by "informational urbanism” [80]. This term was coined by Stallmeyer [77] to analyze "spatial transformations brought about by informational developments” [78, p. 2].

What is a "smart" or an "informational" city? In some scientific studies, definitions or approaches of a "smart city” are collected [e.g., 2,14,15,62,63]. All definitions stress the importance of ICT for the $21^{\text {st }}$ century city [5]. Smart cities bank on ambient intelligence in information spaces city-wide [66] as well as in homes [13]; they are built on results of computer science, information science and cybernetics [56]. However, the term "smart city" is fuzzy $[5,15,37,64]$ and has its origins rather in marketing than in science; for example, the computer company IBM holds the trademark "smarter cities" and applies it in its smarter city campaign [76]. We can identify two different concepts of the "smartness" of cities, one in a narrower sense of the concept and the other in a broader sense.

Narrower concept: In the "vision of a smart city", Hall et al. [34] introduce urban centers of the future, which "se- 
cure environmentally green." Here, a smart city is "forward-looking on the environmental front" [14]. This narrow concept of "smartness" is strongly linked to natural resources and energy, transport and mobility, and living conditions, in short, to the green and livable city.

Broader concept: While Chourabi et al. [14] emphasize a smart city being "an icon of a sustainable and livable city," they define "smartness" with eight critical factors (management and organization, technology, governance, policy context, people and communities, economy, built infrastructure, and natural environment) much broader. Similarly, Giffinger et al. [30] define smart cities in a broader sense by an enumeration of essential "characteristics,” i.e. smart economy, people, governance, mobility, environment and living. Such a broad view of smart cities is anticipated by Castells [7] as early as 1989. For Castells, such cities are prototypical for the network society $[8,9,10]$. Both concepts of "smart cities" are important for informational urbanism, but we always have to distinguish between the narrower concept (emphasizing the green and sustainable city) and the broader concept (stressing the entire city as "informational"). In this article, we use "informational city" and "smart city" (in the broader sense) synonymously.

Informational urbanism has theoretical background both in urban studies, city sociology, city economics, architecture and city planning on the one hand as well as in computer science and information science on the other hand. The both building blocks are held together by system science. The common object of all mentioned disciplines is the multi-loop control system "city" and its various subsystems of infrastructures, economics, politics and administration, spaces, as well as location factors; and additionally the information behavior of its stakeholders (i.e., residents, companies, administrations, visitors, etc.).

A similar approach to analyze cities in terms of their informativeness is "urban informatics." While urban informatics emphasizes the roles of people, place and information and communication technology with a focus on cities [27], informational urbanism includes not only ICT, but all kinds of information and (tacit as well as explicit) knowledge.

Our research program on smart cities at the Heinrich Heine University Düsseldorf started in 2010 with the formulation of a theoretical framework $[41,46,79]$. Since 2011, we have performed empirical studies in cities all over the world. Based upon these empirical findings, we adjusted and calibrated the conceptual framework. In our project on (more than 30 ) world cities, we analyzed

- the roles of e-government and m-government in smart cities [35,49,53,54],

- $\quad$ the use of open urban data in mobile applications [50,51],

- $\quad$ the new functions of physical and digital libraries $[52,55,68]$,

- the information behavior of people living or visiting smart cities in terms of their Twitter activities $[25,26]$.
For selected smart cities we studied

- citizen participation on city-level through 311services in the U.S.,

- $\quad$ programs for information literacy instruction [36],

- creativity and entrepreneurship [60],

- $\quad$ labor markets and job polarization [18],

- "spaces of flows" in terms of flows of capital, power, and information [65],

- $\quad$ the culture-dependent use of social media [4].

Additionally, we performed regional analyses and case studies on single cities:

- $\quad$ regional study Japan $[19,20,21,22]$,

- $\quad$ regional study Arabian Gulf [31,44],

- $\quad$ case study Singapore [42],

- $\quad$ case study London, UK [61],

- $\quad$ case studies on ubiquitous cities: Oulu, Finland [73] and New Songdo City, South Korea [38,39].

For details, see the Appendix.

In this article, we will answer two research questions: What is the current state of the conceptual framework of our smart city research? Based upon our empirical findings, what are the main characteristics of smart cities?

\section{Background: From Max Weber to the Internet of Things}

How can we understand cities in the emerging knowledge society? Max Weber’s “The City” from 1921 is one of the first sociological analyses of urban regions [85] in which he stresses the anonymity in cities in contrast to rural regions, their roles as capitalist market centers and as corporate bodies with a definable area. In contrast to Weber, for Georg Simmel, in 1903 [75], the functional magnitude of a metropolis goes beyond its actual boundaries. The metropolis has impact on the mental life of its residents; insofar there is an intensification of emotional and nervous life [75] due to information overload in cities. With Simmel's and Weber's works, city sociology was born. Regarding the information overload in metropoles and-following Simmel-its influences on the minds of residents, a rudimentary form of informational urbanism emerged as well.

From the 1960s onwards, the exploration of world cities has experienced a big boost. A remarkable example is “The World Cities” by Peter Hall [33], who defines world cities as centers of politics, commerce, finance, professional services, luxury consumption and entertainment. For Hall, administrative boundaries are not important; he considers connected regions (such as Randstad Hollanda city conglomerate in The Netherlands including Amsterdam, The Hague, Rotterdam, Utrecht and some smaller towns) as one world city. The economy of cities is analyzed by Jane Jacobs [40]. Jacobs underlines the essential roles of human capital and competition between firms as externalities of economic success of cities. Manuel Castells' book "Informational Cities” [7] exerts mas- 
sive influence on city research. In the network society, as in informational cities, two spaces exist side by side: geographical space ("space of places") and the space of information, money and power streams ("space of flows") created via digital networks. In informational cities the space of flows outperforms the space of places.

Of course, pure "cities of bits" [57], "e-cities" [58] or "cyborg-selves in the networked city" [59] as introduced by William J. Mitchell are not possible. However, besides the physical infrastructures (like streets, rails or airports) with the digital infrastructures a second set of infrastructures arises. Mitchell, in his "e-topia” [58], describes the interplays between both types of infrastructures. So people act-driven by ICT and the Internet-not only in the physical space, but also in the area of information flows, i.e. in the digital space, e.g. in social media.

John Friedmann proposes the "world city hypothesis" [28]. World cities are the centers of the world economy and urban areas with dense patterns of interactions. In a second attempt [29], he defines world cities-following Castells-through their position in the space of flows. On top of Friedmann's world city hierarchy, we find London, New York and Tokyo. For Saskia Sassen [72], "global cities" are centers of the globalized world. They host headquarters of major companies and their suppliers, first of all service providers (financial services, advertising, media, consulting, etc.). All these companies depend on information; face-to-face information flows are as important as global digital information streams. The global city is an extremely intense and dense information loop, so that the city itself becomes an information center. Peter J. Taylor [82] shows that the world cities generate a network formed by leading service companies' power and information flows. Taylor also stressed the "green" component of cities that makes these worth living in. Taylor et al. [83] use the term "cityness" to describe the position of a city in the global network (as opposed to the "townness," which captures the role of a city to its hinterland).

Richard L. Florida [23] identifies the creative class as a driving force of contemporary cities and regions. The economic development of cities is dependent on the 3Ts, i.e. technology (innovation, high concentration of hightech companies), talent (share of highly educated people, but also of the creative folks, recognized by the "Bohemian Index") and tolerance (openness to all ethnic groups, races or forms of life, captured for example through the "Gay Index") [24].

Following Jan Jerde, “community-oriented ideas for architecture" [70] help to create the city as an event in itself. So-called "architainment" [43] with the example of Las Vegas and landmark buildings (after the success of Frank O. Gehry's Bilbao Guggenheim called "the Bilbao effect” [71]) increase the attractiveness of the city.

Data from cell phones and sensor-based devices (e.g., CCTV cameras) and their rapid application in urban systems (for example, in traffic control) lead-according to Carlo Ratti et al. [69] — to "mobile landscapes" and the "real-time city." For Vlacheas et al. [84], the ultimate technological framework of smart cities is the Internet of Things (IoT), because it connects all components of the digital and some of the physical world. IoT technologies such as RFID (radio-frequency identification), embedded sensors and actuator nodes [32] are essential components of urban regions, making informational cities "ubiquitous.”

\section{Conceptual Framework of Smart City Research}

There are three very basic questions: First, what does "city" mean? As we define "smart cities" as typical cities of the knowledge society, the second question arises, how can the "knowledge society" be defined? And, finally, what do "smart" and "informational city" mean?

(1) In line with contemporary city research $[28,33,72$, 82], we define a "city" not through its administrative borders, but by dense interaction patterns. For New York City, for instance, it can be observed that central services have been shifted away from Manhattan and into the suburban regions of Connecticut and New Jersey. The entire economically connected region of New York and environs thus forms the world city New York. As we need statistical data, we have to apply official statistics, which follows administrative borders. (2) We distinguish between "information society" and "knowledge society" [46]. "Information society" refers to a society whose basic innovations are carried by the resource information and in which computers are of great importance. A "knowledge society," on the other hand, is a society which displays all the characteristics of an information society, at which digital information and in which computer networks play important roles. Additionally, explicit knowledge of every kind is available in any place and at any time and is intensively taken advantage of. Furthermore, here the tacit knowledge of knowledge workers is essential for society, economy and administrations. (3) An "informational city" is a typical city of the knowledge society $[79,80]$. Here, all characteristics of the knowledge society appear on the city-level. The smart city is characterized by the two general aspects of cityness and informativeness [21]. Cityness includes building blocks which mainly exhibit the city's position within the network of all cities on the world, especially the indicators of the spaces of flows and the spaces of places as well as the location factors. Informativeness is directed on indicators of the information and knowledge related infrastructures, the knowledge-based sectoral mix and its labor market, the political willingness to create an informational city as well as to foster citizen participation and transparency, the maturity of e-government, the stakeholders' information behavior, and, finally, problem areas. All these elements discussed in smart city literature are summarized in Figure 1, building the conceptual model for our research project. How can the status of a smart city in terms of its cityness and informativeness be measured? 

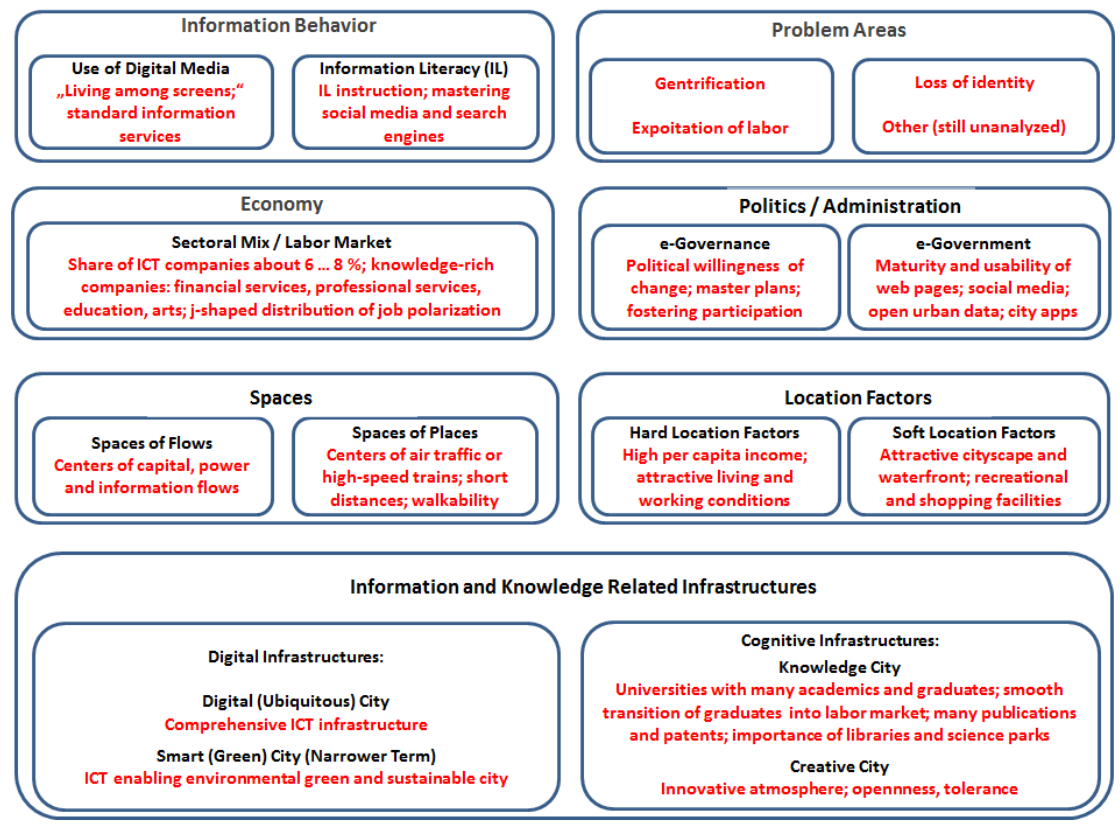

Figure 1. Conceptual framework of smart cities

(in red: essential characteristics of prototypical smart cities).

The large number of indicators requires a wide range of research methods. Our research project employs a systematic combination of methods. First of all a set of cities has been chosen in order to perform a starting point for the analysis. A first constraint was to consider only world cities according to Friedmann [28], Taylor [82] or Sassen [72]. As discussed before, concepts that are often related with informational urbanism are the approaches of "knowledge," "smart", "digital" and "creative city." Thus, initially 31 world cities have been examined that satisfy at least one of these criteria according to an extensive literature search. In a further stage of the project, the set of investigated cities respectively regions has been expanded in order to examine some special regions where e.g. the government has master plans to enter the knowledge society. For this reason, cities such as all the larger Gulf and Japanese cities have been investigated. Our research teams visited all cities between three and nine days, employing methods of rapid ethnography and case research on-site. In the cities, we conducted quantitative surveys and semi-structured qualitative interviews. In detail, a questionnaire has been constructed which is based on the method of ServQual. In total, 18 questions have been designed that are built on existing theoretical frameworks for informational cities and cover all of the topics of the conceptual framework in Figure 1. Further, we worked with bibliometrics and patentometrics and used data from Web of Science and Derwent World Patents Index. The amount of scientific publications as well as the number of patents thereby worked as an indicator for the output of knowledge institutions. When studying e-government and libraries, we analyzed their websites, social media accounts, and mobile applications in terms of maturity, usability, and content. Regarding the latter a classical content analysis has been applied, e.g. in order to establish a typology for the different types of mobile applications that are based on open data of a city. For the analysis, available information on websites and app stores has been used. Content analysis has also been applied in order to identify core services of libraries in smart cities. Finally, whenever possible, we used data from official statistics. Indeed, the problem with statistical data is that most of the cities make use of different classification systems or do not even provide all the necessary data. All the different methods are held together by grounded theory and lead to the formulation of hypotheses and theories.

\section{Results: Smart Cities as Prototypical Urban Regions of the Knowledge Society}

Based on the results of field and desktop research on more than 40 cities as well as-primarily-on semistructured interviews with experts in those cities, we are going to present a comprehensive catalog of essential characteristics of smart cities (or informational cities; from now on "ICs"), all of them being research areas of informational urbanism (and waiting for further, more detailed scientific analyses).

\section{Information and knowledge related infrastructures}

In accordance with Fietkiewicz and Stock [22], we divide the information and knowledge related infrastructures into two more technological aspects of ubiquitous city and smart city (in the narrower sense) and into more cognitive aspects of knowledge city and creative city. 
Digital (ubiquitous) city. ICs put comprehensive ICT infrastructures into the whole urban area and develop a digital (ubiquitous) city. There are great differences between the construction of a new IC and the reconstruction of an existing city towards an IC [3]. For new cities, developed from scratch (as Songdo City in Korea or Masdar City in Abu Dhabi, UAE), ICT is integrated into the city as well as into private homes from the very beginning $[38,39]$. Here, problems arise in missing urbanity. On the other side, old cities with an evolved urbanity are confronted with a reconstruction of the community as a living organismleading to massive (legal, social and political) adjustment problems during ICT integration. Oulu in Northern Finland is an example of an "old" and at the same time ubiquitous city [73]. In Oulu, we found that media poles (in form of large interactive screens distributed all over the city) are not well accepted by inhabitants due to the much simpler use of their own smartphones. Contrariwise, the offer of city-wide free WiFi is broadly welcomed.

Smart city (narrower term). ICs increase the quality of life of its residents through the use of ICT in green and sustainable projects. Most of them market these actions using the buzzword "smart city." Smart city actions include projects of "smart mobility and transportation," as in Shanghai, China, and Tokyo, Japan [22].

An important part of Songdo's smart infrastructure is its waste management system. There are no trash trucks, but an intelligent system which collects the residents' trash in the corridors, distributes it through tunnels, separates the garbage automatically and finishes it in a processing center. Nearly all our interview partners in Songdo report on very good experiences with this smart waste disposal system [38,39].

Knowledge city. ICs take the production and use of scientific, technical, medical (STM) knowledge, but also of everyday knowledge very serious and build on education, their universities and science parks. The advancement of knowledge cities is measureable [44], by science input indicators (knowledge infrastructures, academics, expenditures on R\&D) and output indicators (amount of STM publications and patents as well as number of graduates). In cities on the Arabian Gulf we found world-class infrastructures (as Education City and Qatar University in Doha), mostly imported knowledge (insofar most of the academics are expats) and a very problematic transition of the native graduates into the labor markets as natives prefer to work in well-paid routine jobs over knowledge-intensive jobs in private companies or institutions of higher education [44].

Some ICs bank on their public libraries and transform them into comprehensive information centers including physical as well as digital library services [52,55]. In ICs, libraries become important elements of the cities' knowledge infrastructures. They re-define their role in society and create physical spaces for learning and meeting as well as digital spaces for providing information. Based upon our calculated score on physical and digital library services, the Vancouver Public Library performed best among all analyzed informational world cities [52]. In Doha, Qatar, we found a new type of library. The Qatar National Library combines all functions of public libraries, academic libraries and the national library, be it physical or digital, in only one library, generating synergies. It is located in Doha's Education City in close proximity to all branch campuses in Qatar [44].

Creative city. Many ICs understand openness and tolerance in the sense of Florida [23] as a prerequisite for creative actions, thus establishing the "creative city" (prime example: San Francisco, CA, USA). In some creative cities we are able to identify theater clusters (as Broadway in New York or West End in London) or clusters of galleries and artists' studios (as M50 in Shanghai).

In ICs located in the United States and (to lesser extend) in Asia (but surprisingly not in Europe) creativity correlates positively with economic welfare [60].

\section{Economy and labor markets}

We were able to identify key branches driving the development towards an informational city. In ICs, we find many companies in the information and communication sector. In London [61], about 8\% of all employees work in such an ICT firm; in Singapore [42], the share is 6.5\%. Further important (always very knowledge-rich) labor markets are financial and insurance activities (in London 13\% and in Singapore $11.8 \%$ of the entire work force), professional, scientific and technical activities (in London 13\% and in Singapore 16.3\%), education (in London $8 \%$ and in Singapore 5.4\%) and arts, entertainment and recreation (in London 3\%, in Singapore 5.4\%). Obviously, it is not (or not only) the labor market of ICT itself (with 6 to $8 \%$, its share at the entire labor market is not that high), which dominates an IC, but-based upon ICT and information services-so do knowledge-rich industries as financial services and professional, scientific and technical services.

In many cities of the world, researchers observed an u-shaped curve of the development of work force. Informatization is accompanied by the automatization of large economic areas. Routine tasks are increasingly being performed by (information) machines; the corresponding jobs (such as accounting or operating machinery) require fewer workers. For the workers, then, there remain the tasks that have not been automatized, and these are divided into manual (e.g. cleaning or building) and analytic (e.g. research and development) and interactive labor (e.g. management). The labor market in developed societies is split into well-paid (and well-trained) workers and (very) badly paid workers with limited qualifications-employees in the middle segment of education and income will, tendentially, disappear, due to the increasing automatization of their former activities. In contrast to general job polarization, some ICs exhibit for the native population a j-shaped curve: There is no increase of low-income jobs, but a high increase of well-paid occupations [18]. Low-income jobs are performed by foreign workers who have to leave the country when their job is finished. Examples are Singapore and all cities on the Arabian Gulf [31]. 


\section{Spaces}

Some of the informational world cities occupy prominent positions in the "space of flows." They have a central position in international money flows (by major stock exchanges; prime examples are New York and London), power flows (through headquarters of important companies in their city as for example London, New York, Hong Kong, Paris, Tokyo or Singapore) and information flows (through global cooperation in business and science) [65].

Face-to-face information flows are fostered through MICE (meetings, incentives, conferences, events). A good example for a prospering MICE economy can be found in Doha, Qatar [31]. Examples are the Qatar Motor Show (each year), the World Climate Summit (2012) and the planned FIFA World Cup (2022).

ICs are within easy reach in the "space of places," above all by air traffic and by high-speed trains as, e.g., Frankfurt/M., Germany, where air and rail passengers find -inside one complex of buildings - an international airport, a high-speed train station, and a local traffic (S-Bahn) station [67]. Successful air-rail intermodal agreements lead to benefits for the customers, the airlines and airports, the rail operators and, finally, the environment [11].

Many of the ICs (as well as many other cities) are well aware of short distances, walkability, cycle-friendly traffic [17] and the preference of public transport over private automotive traffic, but they still suffer (despite sometimes introduced city tolls for cars) to extremely heavy car traffic in inner city areas. A positive counterexample is Singapore with very low individual transport (due to high car taxes). In Seoul, Korea, a highway was destructed in favor of the renaturation of a small river [12]. Newly build large metro systems (as in Bejing, Shanghai, Hong Kong, or Singapore) reduce private traffic; environmental-friendly electric or hybrid-busses and lots of green spaces downscale $\mathrm{CO}_{2}$ emissions (as in San Francisco, CA).

\section{Politics and administration}

One of the key objectives for the success of planning and constructing ICs is the political willingness of the city's administration to build or re-build the city under the conditions of the knowledge society. Mostly those governance-oriented ideas are fixed in master plans; always they are adequately funded either by public or private funds. In Singapore $[42,48]$, we are able to identify political programs for the construction of a knowledge society since 1992 ("Intelligent Island”), followed by numerous further master plans as, e.g., "Intelligent Nation 2015" or the current development of the "Smart Nation Platform." A political objective is to foster citizen participation and to understand citizens as co-creators of the present and future city.

Following Mainka, Hartmann and Meschede [50], ICs' administrations rely heavily on e-government [49], m-government (applying mobile apps and websites) [50] and e-participation (through social media channels, mobile applications, and civic hotlines - in the U.S. realized as 311-services). Some governments communicate with their stakeholders via elaborate websites (in terms of maturity and usability). "Maturity" means to tap the full potential of information dissemination, communication, transaction, interoperability of governmental services, and participation [49]; "usability" refers to not stressing users watching and navigating through websites. We found top mature e-government websites in New York, NY, Singapore, and Milan, Italy [49]; top usable sites come from Vienna, Austria, but also from Seoul, Korea, and Shanghai, China [49].

All ICs prefer to use additionally social media (especially Facebook, Twitter, and YouTube [35]). In the analyzed ICs, the highest rate of activity was found on Twitter with 135 tweets per month and city on average [54].

Paris' social media channels achieves by far the highest number of reactions (here, likes on Facebook), followed by Hong Kong (here, followers on Twitter and Weibo), Munich (likes on Facebook), Shenzhen (Twitter/Weibo) and San Francisco (likes) [53].

Governments in ICs tend to open their non-personal data ("open urban data") for reuse by everyone. Open urban data are data from official statistics and from sensor-based services; they are combinable with user-generated content, business data (e.g., opening hours) and other open data (e.g., street maps) [51]. Prime examples for open data policies are Hong Kong, China, SAR, and Vienna, Austria [50]. Many ICs offer m-apps based upon their open urban data. Those m-apps are produced and financed either by governmental bodies or by private persons or companies (and so for free for government agencies). Examples for a government-driven m-app development are Hong Kong, China, and Barcelona, Spain; an example for non-governmentdriven development is Vienna, Austria, while Singapore applies a mixed strategy [50]. In some cities (as in Amsterdam, Barcelona and Paris), hackathons help to create urban m-apps with value-added city services [51].

\section{Location factors}

ICs exert attractive living, working and studying spaces (and other hard locational factors, most important a high wage level) as well as soft location factors (such as a fascinating city and optimal shopping and leisure activities) and a "magnet effect" on potential companies, employees and tourists. London, UK, banks on its historically grown urbanism; most Arabian Gulf cities prefer huge high-end shopping malls and futuristic cityscapes. Former industrial areas near to waterfronts are redeveloped towards attractive wards. But architectural preservation is selective and tries partly to assert historical distinctness [1]. Such distinct historical waterfront transformations can be found in San Francisco (Pier 39), Chicago (Navy Pier) or London (south banks of river Thames); but there are also distinct new constructions of waterfronts as, e.g., in Doha (West Bay), Abu Dhabi (Corniche), and New York (Brooklyn Waterfront Greenway).

\section{Information behavior}

Simmel [75] stressed the picture of emotionally affected people in the city due to information overload. In contrast to Simmel's view on the city around 1900, nowadays 
informational cities distribute information ubiquitous and provoke information overload to a much higher degree. Residents are living among screens [16], not only with their smartphones, but also with big screens presenting news or advertising at bus stops, inside public transport and at public places (such as Times Square, New York City).

In the upcoming knowledge society the citizens' information literacy becomes a basic skill. Information literacy includes the abilities of creation and representation as well as of searching and finding information [81]. Many public as well as academic libraries in well-developed ICs offer courses in information literacy [36].

Due to network effects information markets on the Internet tend to quasi-monopolistic structures [46]. There is only one standard service in a certain market and a certain world region. Google dominates in the search engine market in many regions, but not in Russia (here it is Yandex), South Korea (Naver) and China (Baidu). While Facebook dominates the Social Network Services market in many countries, Russian users prefer Vkontakte [4]. If we study information behavior in ICs, we have to consider these world-wide and local standards.

A globally successful microblogging service is Twitter (exception: China; here it is Weibo). Förster et al. [25,26] collected more than 18 million tweets from the ICs and on those ICs. Paris in France has the highest amount of tweets from the city (found by searching for geo-location), while Tokyo in Japan is in lead by the number of tweets on the city (found by search terms).

Problem areas: Gentrification, exploitation of labor, and loss of identity

We have to pinpoint negative aspects of some specific informational cities. According to our interview partners, the reasons of these undesirable developments can often be found more in cultural and societal values than in the advancement towards the knowledge society.

We see gentrification, i.e. the shift of "control and use of spaces ... from lower-income to higher-income social groups" [47, p. 200], in two forms. In some cities people with low incomes are dispelled from attractive downtown locations (as in Tokyo, Japan [21]); and we observe people who are not able to migrate into ubiquitous cities due to their low income (e.g., in Songdo).

In Arab cities, but also in Singapore, the workforce mainly consists of expats. One cannot overlook the fact that well-trained professional groups are welcomed and highly paid, while unskilled foreign workers have to suffer from relatively low incomes and sometimes slave-like exploitations. However, the native Arab population is confronted with a massive foreign workforce given up to nearly $90 \%$ expat rates (as in Dubai and in Doha). For some citizens in Arab Gulf cities, the dark side of this special kind of globalization leads on to feel as strangers in their own country. Political counteractions as "Emiratization," "Qatarization," etc. with the goal of re-integrating domestic workforce into jobs outside (very well paid) public services still fail [44].
Some of our interview partners talked about the possible loss of identity of "their" city: In many cities of the world the same architects and the same construction companies design exchangeable cityscapes, and in their shopping malls and shopping streets always nearly the same products are offered. Due to globalization, there is probably no single IC which does not host at least one Gucci or Cartier shop.

Maybe there are further, still unanalyzed, problem areas of ICs. Do such cities exhibit problems with crime rates, and, if yes, are they using ICT to combat crime? Does information overload, as Simmel [75] mentioned, lead to specific physical diseases or mental illness?

\section{Conclusion}

Informational urbanism is a new interdisciplinary and holistic research topic which studies smart (in the broader sense of informational) cities. The theoretical background of informational urbanism starts with the city sociology of Weber and Simmel and takes its way through city research by Hall, Jacobs, Castells, Friedmann, Sassen and Taylor, creativity research by Florida, architecture by, e.g., Jerde or Ratti, and ending with the Internet of Things.

The conceptual framework of informational urbanism consists of seven building blocks, of which five are subsystems of the system of a smart city, the sixth represents the information behavior of the cities' stakeholders, and the last one includes problem areas:

- information and knowledge related infrastructures (digital/ubiquitous city, smart city in the narrower-green and sustainable-sense, knowledge city, and creative city),

- $\quad$ economy (sectoral mix and labor market),

- $\quad$ spaces (spaces of capital, power and information flows, spaces of places),

- politics and administration (e-governance and e-government),

- location factors (especially the city's magnet effect),

- information behavior (use of digital media and the stakeholders' information literacy), and

- problem areas (gentrification, exploitation of labor, loss of identity, and other still unanalyzed problems).

Informational urbanism considers not only ICT, but all kinds of information and knowledge, including tacit as well as explicit knowledge. In the course of our field and desktop research on more than 40 smart cities all around the world, we are able to show that informational urbanism's conceptual framework indeed works satisfactorily so far. An important limitation of our paper is the still small number of studied cities. In future, we will try to validate our proposed framework in different contexts, e.g.: Are there different paths of development into smart cities in old regions (as New York, NY) and in regions constructed from 
scratch (as Dubai)? Are there specific ways to smart cities in Europe, the Americas, South-East Asia and Arabia?

Acknowledgment. We like to thank Isabella Peters (Leibniz Information Centre for Economics and Kiel University, Germany), Katsiaryna S. Baran, Maria Henkel, Fee Hilbert, Adriana Kosior, Sviatlana Khveshchanka, Rena Möhlmann, Sandra Pyka, Steffen Rölike, and Laura Schumann (all of Heinrich Heine University Düsseldorf) for providing data and for valuable discussions on earlier versions of this paper.

\section{Appendix: Analyzed Cities}

(1) World city project: Amsterdam (Netherlands), Barcelona (Spain), Beijing (China), Berlin (Germany), Boston (U.S.A.), Chicago (U.S.A.), Dubai (U.A.E.), Frankfurt (Germany), Helsinki (Finland), Hong Kong (China, SAR), Kuala Lumpur (Malaysia), London (United Kingdom), Los Angeles (U.S.A.), Melbourne (Australia), Milan (Italy), Montréal (Canada), Munich (Germany), New York (U.S.A.), Paris (France), San Francisco (U.S.A.), Sao Paulo (Brazil), Seoul (South Korea), Shanghai (China), Shenzhen (China), Singapore (SG), Stockholm (Sweden), Sydney (Australia), Tokyo (Japan), Toronto (Canada), Vancouver (Canada), Vienna (Austria);

(2) Regional project on Japanese cities: Tokyo, Yokohama, Osaka, Kyoto;

(3) Regional project on Gulf cities: Kuwait City (Kuwait), Manama (Bahrain), Doha (Qatar), Abu Dhabi, Dubai, Sharjah (all United Arab Emirates), Muscat (Oman);

(4) Project on ubiquitous cities: Oulu (Finland), New Songdo City (South Korea), Barcelona (Spain).

\section{References}

[1] A. Airas, P. V. Hall, and P. Stern, "Asserting historical 'distinctiveness' in industrial waterfront transformation", Cities, 44, 2015, pp. 86-93.

[2] V. Albino, U. Berardi, and R. M. Dangelico, "Smart cities: Definitions, dimensions, performance, and initiatives”, Journal of Urban Technology, 22(1), 2015, pp. 3-21.

[3] M. Angelidou, "Smart city policies: A spatial approach", Cities, 41, 2014, pp. S3-S11.

[4] K. S. Baran, and W. G. Stock, “Acceptance and quality perceptions of social network standard and non-standard services in different cultures”, in C. Stephanidis (Ed.), HCI International 2015 - Posters' Extended Abstracts. HCI International 2015, Los Angeles, CA, USA, August 2-7, 2015. Proceedings Part II (pp. 65-70), Springer, Cham, Switzerland, 2015.

[5] A. Caragliu, C. Del Bo, and P. Nijkamp, "Smart cities in Europe”, Journal of Urban Technology, 18(2), 2011, pp. 6582.

[6] F. J. Carillo, T. Yigitcanlar, B. García, and A. Lönnqvist, Knowledge and the City. Concepts, Applications and Trends of Knowledge-based Urban Development, Routledge, New York, NY, 2014.
[7] M. Castells, The Informational City. Information Technology, Economic Restructuring, and the Urban-Regional Process, Blackwell, Oxford, UK, and Cambridge, MA, 1989.

[8] M. Castells, The Rise of the Network Society, Blackwell, Malden, MA, 1996.

[9] M. Castells, The Power of Identity, Blackwell, Malden, MA, 1997.

[10] M. Castells, End of Millennium, Blackwell, Malden, MA, 1998.

[11] P. Chiambaretto, and C. Decker, "Air-rail intermodal agreements: Balancing the competition and environmental effects”, Journal of Air Transport Management, 23, 2012, pp. 36-40.

[12] M. R. Cho, "The politics of urban nature restoration. The case of Cheonggyecheon restoration in Seoul, Korea", International Development Planning Review, 32(2), 2010, pp. $145-165$.

[13] D. J. Cook, "How smart is your home?", Science, 335(1579), 2012, pp. 1579-1581.

[14] H. Chourabi, T. Nam, S. Walker, J. R. Gil-Garcia, S. Mellouli, K. Nahon, T. A. Pardo, and H. J. Scholl, "Understanding smart cities: An integrative framework", in Proceedings of the $45^{\text {th }}$ Hawaii International Conference on System Sciences (pp. 2289-2297), IEEE Computer Society, Washington, DC, 2012.

[15] A. Cocchia, "Smart and digital city: A systematic literature review", in R. P. Dameri, and C. Rosenthal-Sabroux (Eds.), Smart City. How to Create Public and Economic Value with High Technology in Urban Space (pp. 13-43), Springer, Cham, Switzerland, 2014.

[16] B. David, and R. Chalon, "Living among screens in the city”, Lecture Notes in Computer Science, 9170, 2015, pp. 509-518.

[17] L. Dixon, "Bicycle and pedestrian level-of-service performance measures and standards for congestion management”, Journal of the Transportation Research Board, 1538, 1996, pp. 1-9.

[18] R. Dornstädter, S. Finkelmeyer, and N. Shanmuganathan, "Job-Polarisierung in informationellen Städten”, Information - Wissenschaft und Praxis, 62(2-3), 2011, pp. 95-102.

[19] K. J. Fietkiewicz, and S. Pyka, "Development of informational cities in Japan: A regional comparison”, International Journal of Knowledge Society Research, 5(1), 2014, pp. 69-82.

[20] K. J. Fietkiewicz, S. Pyka, and W. G. Stock, "Evaluating infrastructures of the $21^{\text {st }}$ century city: Informational cities in Japan as case studies”, Advances in Research, 3(3), 2015, pp. 297-311.

[21] K. J. Fietkiewicz, and W. G. Stock, "Cityness and informativeness of the emerging informational cities in Japan”, Creative and Knowledge Society, 4(1), 2014, pp. 4356.

[22] K. J. Fietkiewicz, and W. G. Stock, "How 'smart' are Japanese cities? An empirical investigation of infrastructures and governmental programs in Tokyo, Yokohama, 
Osaka and Kyoto, in Proceedings of the $48^{\text {th }}$ Hawaii International Conference on System Sciences (pp. 2345-2354), IEEE Computer Science, Washington, DC, 2015.

[23] R. L. Florida, Cities and the Creative Class, Routledge, New York, NY, and London, UK, 2005.

[24] R. L. Florida et al., Creativity and Prosperity: The Global Creativity Index, Martin Prosperity Institute, Toronto, ON, 2011.

[25] T. Förster, L. Lamerz, A. Mainka, and I. Peters, “The tweet and the city: Comparing Twitter activities in informational world cities", in Proceedings of the $3^{\text {rd }}$ DGI Conference (pp. 101-118), DGI, Frankfurt a. M., Germany, 2014.

[26] T. Förster, and A. Mainka, "Metropolises in the Twittersphere: An informetric investigation of informational flows and networks", International Journal of GeoInformation, 4, 2015, pp. 1894-1912.

[27] M. Foth, J. H.-J. Choi, and C. Satchell, "Urban informatics", in Proceedings of the ACM 2011 Conference on Computer Supported Work (pp. 1-8), ACM, New York, NY, 2011.

[28] J. Friedmann, “The world city hypothesis”, Development and Change, 17, 1986, pp. 69-83.

[29] J. Friedmann, "Where we stand. A decade of world city research", in P. Knox, and P. Taylor (Eds.), World Cities in a World-System (pp. 21-47), Cambridge Univ. Press, Cambridge, UK, and New York, NY, 1995.

[30] R. Giffinger, C. Fertner, H. Kramar, R. Kalasek, N. Pichler-Milanovic, and E. Meijers, Smart Cities - Ranking of European Medium-Sized Cities, Centre of Regional Science, Vienna, Austria, 2007.

[31] J. Gremm, J. Barth, and W. G. Stock, "Kuwait is the past, Dubai is the present, Doha is the future: Informational cities on the Arabian Gulf”, International Journal of Knowledge Society Research, 6(2), 2015, pp. 51-64.

[32] J. Gubbi, R. Buyya, S. Marusic, and M. Palaniswami, "Internet of Things (IoT): A vision, architectural elements, and future directions", Future Generation Computer Systems, 29, 2013, pp. 1645-1660.

[33] P. Hall, The World Cities, Weidenfeld and Nicolson, London, UK, 1966.

[34] R. E. Hall, B. Bowerman, J. Braverman, J. Taylor, H. Todosow, and U. von Wimmersperg, "The vision of a smart city", in $2^{\text {nd }}$ International Life Extension Technology Workshop, Paris, France, September 28, 2000.

[35] S. Hartmann, A. Mainka, and I. Peters, "Government activities in social media”, in P. Parycek, and N. Edelmann (Eds.), CeDEM13. Conference for E-Democracy and Open Government (pp. 159-171). Donau-Universität Krems, Krems, Austria, 2013.

[36] M. Henkel, Educators of the information society: Information literacy instruction in public and academic libraries of Canada. In Proceedings of the $78^{\text {th }}$ ASIS\&T Annual Meeting, November 6-10, 2015, St. Louis, Missouri (pp. 110), Association for Information Science and Technology, Silver Spring, MD, 2015.

[37] R. G. Hollands, "Will the real smart city please stand up?”, City, 12(3), 2008, pp. 303-320.
[38] A. Ilhan, R. Möhlmann, and W. G. Stock, "Customer value research and ServQual surveys as methods for information need analysis. The ubiquitous city Songdo as a case study", in Proceedings of the $14^{\text {th }}$ International Symposium of Information Science (pp. 457-468), Hülsbusch, Glückstadt, Germany, 2015.

[39] A. Ilhan, R. Möhlmann, and W. G. Stock, "Citizens' acceptance of u-life services in the ubiquitous city Songdo", in M. Foth, M. Brynskov, and T. Ojala (Eds.), Citizen's Right to the Digital City. Urban Interfaces, Activism, and Placemaking (pp. 215-229), Springer, Singapore, SG, 2015.

[40] J. Jacobs, The Economy of Cities, Random House, New York, NY, 1969.

[41] S. Khveshchanka, and A. Mainka, "Informational cities as urban centers of the knowledge era", in My Ideal City. Scenarios for the European City of the $3^{\text {rd }}$ Millennium (pp. 117-122), Università Iuav di Venezia, Venezia, Italy, 2011.

[42] S. Khveshchanka, A. Mainka, and I. Peters, "Singapur: Prototyp einer informationellen Stadt”, Information - Wissenschaft \& Praxis, 62(2/3), 2011, pp. 111-121.

[43] N. M. Klein, The Vatican to Vegas. A History of Special Effects, New Press, London, UK, and New York, NY, 2004.

[44] A. Kosior, J. Barth, J. Gremm, A. Mainka, and W. G. Stock, "Imported expertise in world-class knowledge infrastructures: The problematic development of knowledge cities in the Gulf region”, Journal of Information Science Theory and Practice, 3(3), 2015, pp. 17-44.

[45] K. Kourtit, P. Nijkamp, and T. de Noronha Vaz, "Cities in a shrinking globe”, International Journal of Global Environmental Issues, 14(1/2), 2015, pp. 6-16.

[46] F. Linde, and W. G. Stock, Information Markets. A Strategic Guideline for the I-Commerce, De Gruyter Saur, Berlin, Germany, and New York, NY, 2011.

[47] A. Madanipour, Knowledge Economy and the City. Spaces of Knowledge, Routledge, London, UK, and New York, NY, 2011.

[48] A. Mahizhnan, "Smart cities. The Singapore case", Cities, 16(1), 1999, pp. 13-18.

[49] A. Mainka, K. J. Fietkiewicz, A. Kosior, S. Pyka, and W. G. Stock, "Maturity and usability of e-government in informational world cities", in E. Ferrari, and W. Castelnovo (Eds.), Proceedings of the $13^{\text {th }}$ European Conference on e-Government (pp. 292-300), Academic Conferences and Publishing International, Reading, UK, 2013.

[50] A. Mainka, S. Hartmann, C. Meschede, and W. G. Stock, "Mobile application services based upon open urban government data", in Proceedings of iConference 2015. Newport Beach CA, USA, March 24-27, 2015 (15 pp.).

[51] A. Mainka, S. Hartmann, C. Meschede, and W. G. Stock, "Open government: Transforming data into valueadded city services", in M. Foth, M. Brynskov, and T. Ojala (Eds.), Citizen's Right to the Digital City. Urban Interfaces, Activism, and Placemaking (pp. 199-214), Springer, Singapore, SG, 2015.

[52] A. Mainka, S. Hartmann, L. Orszullok, I. Peters, A. Stallmann, and W. G. Stock, "Public libraries in the 
knowledge society: Core services of libraries in informational world cities”, Libri, 63(4), 2013, pp. 295-319.

[53] A. Mainka, S. Hartmann, W. G. Stock, and I. Peters, "Government and social media: A case study of 31 informational world cities", in Proceedings of the $47^{\text {th }}$ Hawaii International Conference on System Sciences (pp. 1715-1724), IEEE Computer Society, Washington, DC, 2014.

[54] A. Mainka, S. Hartmann, W. G. Stock, and I. Peters, "Looking for friends and followers: A global investigation of governmental social media use", Transforming Government: People, Process and Policy, 9(2), 2015, pp. 237-254.

[55] A. Mainka, and S. Khveshchanka, "Digital libraries as knowledge hubs in informational cities", in Libraries in the Digital Age (LIDA), Proceedings Vol. 12, 18 - 22 June 2012, University of Zadar, Zadar, Croatia, 2012.

[56] F. A. Maymir-Durcharme, and L. A. Angelelli, “The smarter planet: Built on informatics and cybernetics”, Journal of Systemics, Cybernetics and Informatics, 12(5), 2014, pp. 49-54.

[57] W. J. Mitchell, City of Bits. Space, Place, and the Infobahn, MIT Press, Cambridge, MA, 1995.

[58] W. J. Mitchell, e-topia. Urban Life, Jim-but not as We Know It, MIT Press, Cambridge, MA, 1999.

[59] W. J. Mitchell, Me++. The Cyborg-self and the Networked City, MIT Press, Cambridge, MA, 2003.

[60] D. Murugadas, S. Vieten, J. Nikolic, K. J. Fietkiewicz, and W. G. Stock, "Creativity and entrepreneurship in informational metropolitan regions", Journal of Economics and Social Development, 2(1), 2015, pp. 14-24.

[61] D. Murugadas, S. Vieten, J. Nikolic, and A. Mainka, "The informational world city London", Journal of Documentation, 71(4), 2015, pp. 834-864.

[62] T. Nam, and T. A. Pardo, "Conceptualizing smart city with dimensions of technology, people, and institutions", in Proceedings of the $12^{\text {th }}$ Annual International Conference on Digital Government Research (pp. 282-291), ACM, New York, NY, 2011.

[63] P. Neirotti, A. De Marco, A. C. Cagliano, G. Mangano, and F. Scorrano, "Current trends in Smart City initiatives: Some stylised facts”, Cities, 38, 2014, pp. 25-36.

[64] E. Negre, and C. Rosenthal-Sabroux, "Smart cities: A salad bowl of citizens, ICT and environment”, in A. Vesco, and F. Ferrero (Eds.), Handbook of Research on Social, Economic, and Environmental Sustainability in the Development of Smart Cities (pp. 61-78), IGI Global, Hershey, PA, 2015.

[65] B. Nowag, M. Perez, and M. Stuckmann, "Informationelle Weltstädte: Indikatoren zur Stellung von Städten im 'Space of Flow'”, Information - Wissenschaft und Praxis, 62(2-3), 2011, pp. 103-109.

[66] M. O’Grady, and G. O’Hare, "How smart is your city?”, Science, 335(1579), 2012, pp. 1581-1582.

[67] R. A. Payne, "Frankfurt airport: Pioneering intermodal air-rail developments”, Japan Railway \& Transport Review, 19, 1999, pp. 31-35.

[68] I. Peters, S. Hartmann, and A. Mainka, "Social media use and outreach of selected public libraries in informational world cities”, in I. Huvila (Ed.), Proceedings of the Second Association for Information Science and Technology ASIS\&T European Workshop (pp. 79-93), Åbo Akademie University, Åbo/Turku, Finland, 2013.

[69] C. Ratti, D. Frenchman, R. M. Pulselli, and S. Williams, "Mobile landscapes: Using location data from cell phones for urban analysis", Environment and Planning B: Planning and Design, 33(5), 2006, pp. 727-748.

[70] J. Revis, “The art of architecture," Interview with Jon Jerde, Art and Living, Spring/Summer, 2008, pp. 69-76.

[71] W. Rybczynski, “The Bilbao effect”, The Atlantic, 290(2), 2002, pp. 138-142.

[72] S. Sassen, The Global City. New York, London, Tokyo, $2^{\text {nd }}$ Ed., Princeton Univ. Press, Princeton, NJ, 2001.

[73] L. Schumann, and W. G. Stock, “Acceptance and use of ubiquitous cities' information services", Information Services \& Use, 35(3), 2015, pp. 191-206.

[74] D. H. Shin, "Ubiquitous city. Urban technologies, urban infrastructure and urban informatics”, Journal of Information Science, 35(5), 2009, pp. 515-526.

[75] G. Simmel, “Die Großstädte und das Geistesleben”, in Die Großstadt. Jahrbuch der Gehe-Stiftung, Vol. 9 (pp. 185-206), 1903.

[76] O. Søderström, T. Paasche, and F. Klauser, "Smart cities as corporate storytelling”, City, 18(3), 2014, pp. 307320.

[77] J. C. Stallmeyer, "Landscapes of informational urbanism”, Journal of Landscape Architecture, 6(3), 2009, pp. 34-39.

[78] J. C. Stallmeyer, Building Bangalore. Architecture and Urban Transformation in India's Silicon Valley, Routledge, London, UK, and New York, NY, 2011.

[79] W. G. Stock, "Informational cities. Analysis and construction of cities in the knowledge society", Journal of the American Society for Information Science and Technology, 62(5), 2011, pp. 963-986.

[80] W. G. Stock, "Informational urbanism", Journal of Systemics, Cybernetics and Informatics, 13(6), 2015, pp. 6269.

[81] W. G. Stock, and M. Stock, Handbook of Information Science, De Gruyter Saur, Berlin, Germany, and Boston, MA, 2013.

[82] P. J. Taylor, World City Network. A Global Urban Analysis, Routledge, London, UK, 2004.

[83] P. J. Taylor, M. Hoyler, and R. Verbruggen, "External urban relational process. Introducing central flow theory to complement central place theory", Urban Studies, 47(13), 2010, pp. 2803-2818.

[84] P. Vlacheas, R. Giaffreda, V. Stavroulaki, D. Kelaidonis, V. Foteinos, G. Poulios, P. Demestichas, A. Somov, A. R. Biswas, and K. Moessner, "Enabling smart cities through a cognitive management framework for the internet of things”, IEEE Communications Magazine, 51(6), 2013, pp. 102-111.

[85] M. Weber, "Die Stadt. Eine soziologische Untersuchung”, Archiv für Sozialwissenschaft und Sozialpolitik 47, 1921, pp. 621-772. 